\title{
Visible Teaching Design of Middle School English Listening and Speaking Class from the Perspective of Task-Based Teaching
}

\author{
Zifan Tang, Qiang Liu* \\ Zhejiang Ocean University, Zhoushan, China \\ *Corresponding Author: Qiang Liu, Zhejiang Ocean University, Zhoushan, China

\begin{abstract}
Given the current situation that English communicative ability is often neglected in middle school classes, more importance should be attached to students' English listening and speaking ability, which requires more priorities. My research finds that students' needs are identical though there is a wide gap in their backgrounds. This paper mainly focuses on the problems that have existed in middle school English listening and speaking classes and puts forward some proposals.
\end{abstract}

Keywords: Visible Learning, Task-based Teaching, Visible Teaching Design

\section{BACKGROUND OF THE STUDY}

The importance of English learning is now drawing a growing attention, especially learner's capacity for communication. All kinds of advanced out-class English listening and speaking lessons have emerged in this context. However, problems still exist in middle school English classes, which are dominated by exam-oriented classes like reading and writing classes. The consequence is that listening and speaking classes are usually ignored. This study consists of 3 parts, including the status or current situation of English listening and speaking classes in middle schools, analysis of the problems that lie in it, some proposals to make practical and effective visible teaching designs of middle school English listening and speaking class from the perspective of task-based teaching.

\subsection{Political Background}

"English new curriculum standard of Compulsory education in China (2018)" notes that students in middle schools should achieve a certain level in listening: 1 . the ability to understand the intention of speakers. 2. the ability to get the main idea of a conversation based on its context. 3. the ability to memorize the general idea and respond appropriately while listening. Meanwhile in speaking: 1 . the ability to express one's own opinions and communicate with others according to a given topic. 2 . the ability to ask for help or acquire information effectively. 3. the able to correct oneself in oral expression(Xu Sheng, 2017)

\subsection{Theoretical Background}

As a relatively mature teaching theory, lots of renowned scholars have explored the area of TBLT (Task-Based Language Teaching). As Jia Zhigao concluded that the task is only a kind of method through which can promote students' thoughts and decision making, providing them with the real communicative environment and the opportunity to use the target language to solve problems, so that language learning would become a meaningful and context based language practice (Jia Zhigao, 2005). The implementation of TBLT should be based on the competence of different language learners, with appropriate difficulty and operability, and be both meaningful and interesting, so as to promote the absorption of language information, help learners adjust the cognitive schema and reconstruct their knowledge structures (Fang Wenli, 2003). Furthermore, three types of factors are summarized that have been commonly reported as difficulties in the process of implementing TBLT, institutional culture related factors, classroom teaching related factors and teacher development related factors (Rebecca Adams \& Jonathan Newton, 2009) .

Researches have been carried out to figure out the differences in English teaching achievements caused by teachers' behaviors. John Hattie promotes the idea of visible learning. One point to mention 
is that here "visible" has no direct connection with vision. "Visible" refers to a mental awareness that teachers are clear about what they are teaching and students know what they are learning, through which students can learn to be their own teacher. Teachers will know the elements that push students to learn (John Hattie, 2012). Furthermore, visible learning syntheses demand that teachers should evaluate their own impact on students and set up conditions that will produce influence on students' learning. Teachers are entailed to seek feedback about their impact so as to modify their teaching behavior and improve the quality of the whole teaching procedure (John Hattie \& Gregory Yates, 2013). The premise of visible learning is that teachers' attention focuses on evaluating and understanding their impact on students. This will naturally bring about maximization of students' learning ability. A key element to achieve this presupposition is teachers' ability to build and evaluate successful teaching programs and learning experiences (John Hattie, 2015).

Visible learning attaches great importance to "teaching" and "learning". It's necessary for students to become the main body of learning, meanwhile teachers need to be clear about the role they play in teaching. Teachers should pay attention to "how to learn", observe the difficulty of learning tasks from the perspective of students, understand students' ability. Appropriate measures are supposed to be applied. At the same time, students are expected to become their own teachers and learn to learn.

\section{RESEARCH PROCESS}

\subsection{Research Objects}

The research objects are middle school students in Zhejiang Province, China. Their ages range from 12 years old to 15 years old.

\subsection{Research Questions}

The questions involved in this questionnaire mainly focus on the following four aspects with TBLT and visible learning in consideration:

- gender

- students' attitudes toward English listening and speaking class and class design

- teachers' behavior in the class

- students' opinions of English listening and speaking class

In order to ensure the validity of the investigation, the definitions of TBLT and visible learning were explained at the beginning of the questionnaire. And the questions are set in the order of gender, respondents' attitudes, 4 TBLT related questions, 4 visible learning related questions and students' views and suggestions on English listening and speaking class to clear away the potential confusion.

\subsection{Data Collection}

This study gave out questionnaires to middle school students in Zhe Jiang Province. As the number of questionnaires a total of 150 questionnaires were issued and 99 valid questionnaires were collected.

Among the 99 respondents of the survey, 38 respondents are males, accounting for $38.38 \%$ and 61 females, accounting for the rest $61.62 \%$.

SPSS is used to analyze the data gathered from returned questionnaires.

Due to insufficient number of the valid questionnaires, there may be some deficiencies in the gathered data, which should be paid more attention to in the following research.

\section{FINDINGS}

\subsection{Correlation between TBLT and Student's Attitudes}

\begin{tabular}{|c|c|}
\hline Figure 1 & $\begin{array}{c}\text { How do teachers have English listening } \\
\text { and speaking classes }\end{array}$ \\
\hline Teachers give tasks and instructions to guide students in class & $0.655^{* *}$ \\
\hline Teachers give more tasks and requirements in class & $0.668^{* *}$ \\
\hline $\begin{array}{c}\text { Teachers use multimedia, acting or games in listening and } \\
\text { speaking classes }\end{array}$ & $0.588^{* *}$ \\
\hline
\end{tabular}


Visible Teaching Design of Middle School English Listening and Speaking Class from the Perspective of Task-Based Teaching

\begin{tabular}{|c|c|}
\hline $\begin{array}{c}\text { Teachers carry out a listening and speaking class through a } \\
\text { variety of assignments }\end{array}$ & $0.557 * *$ \\
\hline \multicolumn{2}{|c|}{$* \mathrm{p}<0.05 * * \mathrm{p}<0.01$} \\
\hline
\end{tabular}

Chart 1 mainly manifests the correlation between individuals' attitudes toward English listening and speaking class and 4 TBLT related English teaching methods (in figure 1). The correlation coefficient between students' attitudes toward English listening and speaking class and "Teachers give tasks and instructions to guide students in class" is 0.655 , which clearly shows that there is a positive correlation between these two elements. In addition, correlation coefficients between whether a student likes English listening and speaking class and other three variants in figure 1 are $0.668,0.588$ and 0.557 severally, indicating the correlations that exist in students' attitudes toward English listening and speaking class and the 3 variants mentioned above are all positive.

Through chart 1 above we can draw a conclusion that TBLT plays a positive role in students' attitudes toward English listening and speaking classes for these teaching methods can help to foster children's care for English learning and make the class more interesting and magnetic. Furthermore, through TBLT teaching methods teachers can help students to catch up with the class and aspire students' enthusiasm for English listening and speaking learning. Thus it's valid for teachers to apply TBLT in their teaching design. With tasks that are easily understandable, topics related and practical, students would more easily become interested in English listening and speaking class and their listening and speaking ability will be improved accordingly in the process of their learning.

\subsection{Correlation between 4 Variants and Students' Attitude, Visible Learning}

\begin{tabular}{|l|l|l|}
\hline \multicolumn{1}{|c|}{ Figure 2 } & \multicolumn{1}{|c|}{$\begin{array}{c}\text { How do teachers have English } \\
\text { listening and speaking classes }\end{array}$} & $\begin{array}{c}\text { English listening and speaking class } \\
\text { reflects the visual teaching theory }\end{array}$ \\
\hline Every class has a given goal & $0.430^{* *}$ & $0.475^{* *}$ \\
\hline $\begin{array}{l}\text { Teachers response actively to } \\
\text { students and encourage every } \\
\text { student }\end{array}$ & $0.575^{* *}$ & $0.588^{* *}$ \\
\hline $\begin{array}{l}\text { Teachers pose questions and } \\
\text { evoke students' thinking in class }\end{array}$ & $0.461^{* *}$ & $0.691^{* *}$ \\
\hline $\begin{array}{l}\text { Teachers check the learned } \\
\text { knowledge by homework and } \\
\text { tests }\end{array}$ & $0.475^{* *}$ & $0.632^{* *}$ \\
\hline \multicolumn{2}{|c|}{${ }^{*} \mathrm{p}<0.05 * * \mathrm{p}<0.01$} \\
\hline
\end{tabular}

Chart 2 shows the correlation between the 4 variants that contain visible learning thoughts and students' attitudes toward English listening and speaking class and visible learning syntheses.

The correlations between the 4 variants in figure 2 and students' attitudes toward English listening and speaking class are $0.430,0.575,0.461$ and 0.475 severally. Obviously, the correlations between the 4 variants and students' attitudes toward English listening and speaking class and visible learning syntheses are positive. Moreover, we can find that students' stance towards school English listening and speaking class is under the influence of teachers' behavior and teaching strategies in class especially their instructions and feedback. However, teachers' instruction in class and their feedback can be easily ignored in middle school listening and speaking class teaching.

In order to forge a better English listening and speaking lesson, explicit instructions are needed, which can help students keep up with the lesson and concentrate on the class. Students also need teachers' affirmative feedback, through which they will know how they are doing in class and what to do afterwards. Furthermore, regular evaluation on students' mastery of learned knowledge is expected. A teacher who gives clear instruction and reacts actively to students is more likely to cultivate students' interest in English learning and an optimal learning climate and then students would gradually develop their love for English listening and speaking class. Finally, they can reap a harvest in English listening.

As for the correlation between visible learning theory and the 4 variants, no surprisingly the ideas of visible learning have already been applied, although indirectly, in middle school English listening and speaking class design. And students reacted actively to the teaching behaviors and strategies that contain visible learning thoughts, showing that visible learning is enforceable and welcomed in 
English listening and speaking class and can pose a positive effect. That is, teachers can improve their listening and speaking class teaching designing with the help of visible learning.

Visible learning focuses on how students learn. Although the ideas of visible learning have been involved in the class design of middle schools listening and speaking classes, in order to take maximum advantage of visible learning in teaching design, teachers need to know about visible learning and then conduct class design under the guidance of visible learning.

\subsection{The Status Quo of English Listening and Speaking Class and Student's Views}

\begin{tabular}{|l|l|l|l|}
\hline Figure 3 & Options & Counts & Proportion \\
\hline \multirow{4}{*}{$\begin{array}{l}\text { English listening and } \\
\text { needs more attention }\end{array}$} & Quite agree & 29 & $29.29 \%$ \\
\cline { 2 - 4 } & Agree & 43 & $43.43 \%$ \\
\cline { 2 - 4 } & Kind of & 19 & $16.16 \%$ \\
\cline { 2 - 4 } & Disagree & 1 & $1.01 \%$ \\
\cline { 2 - 4 } $\begin{array}{l}\text { English listening and speaking class } \\
\text { mainly test-oriented }\end{array}$ & Strongly disagree & 10 & $10.1 \%$ \\
\cline { 2 - 4 } & Quite agree & 18 & $18.18 \%$ \\
\cline { 2 - 4 } & Agree & 20 & $20.2 \%$ \\
\hline \multirow{3}{*}{$\begin{array}{l}\text { English listening and speaking class has } \\
\text { practical meaning and can improve } \\
\text { student' capacity }\end{array}$} & Kind of & 20 & $30.3 \%$ \\
\cline { 2 - 4 } & Disagree & 30 & $11.11 \%$ \\
\cline { 2 - 4 } & Strongly disagree & 11 & $28.28 \%$ \\
\cline { 2 - 4 } & Quite agree & 28 & $38.38 \%$ \\
\hline & Dind of & 38 & $22.22 \%$ \\
\cline { 2 - 4 } & Strongly disagree & 9 & $2.02 \%$ \\
\hline
\end{tabular}

Analysis of chart 3 are mainly given from 3 aspects, including the importance, practical meaning of middle school English listening and speaking class and students' suggestions on it.

In terms of the importance, over $80 \%$ students can recognize the importance of middle school English listening and speaking class when nearly $60 \%$ of them think it is mainly test-oriented. Clearly, the significance of English listening and speaking class has been fully acquainted by students. And their recognition has changed, from paying all their attention to grammar and vocabulary to comprehensive English competence which includes listening and speaking ability.

The importance of English listening and speaking class needs legitimate concern. Language and grammar knowledge is only a part of English learning. Teaching should pay attention to all aspects for students are more likely to archive their goals of integrated development in English after a comprehensive learning.

As for practical meaning, over $85 \%$ of students claim that through English listening and speaking class their communication and listening ability have been improved. Listening and speaking class do improve students' ability, while with the help of visible teaching teachers can provide students with listening and speaking classes that are more attractive and effective.

When it comes to students' suggestions on English listening and speaking class, language environment and chances to speak are most frequently mentioned by respondents, indicating students are eager to have a communicating environment and get more chances to express themselves. It is very important for teachers to listen to students' opinions which can help teachers to improve their curriculum design and their teaching.

From the perspective of the needs of today's society, teaching emphasis is more often placed on the improvement of students' comprehensive ability. While students begin to pay their attention to the improvement of their competence in speaking and listening rather than merely in vocabulary or grammar, they want a comprehensive improvement in English. While the listening and speaking class haven't been attached enough importance in schools. Schools and teachers should pay attention to the role of English listening and speaking class.

The whole process of language acquisition needs a certain language environment, which can provide learners with sufficient language input and then it becomes possible for them to be competent in listening and speaking. To fulfill this desired result, teachers need to compose a communicative 
language learning environment, give students speaking opportunities and encourage students to express themselves in class.

Therefore, practical and effective proposals are needed to help teachers to improve the teaching design of middle school English listening and speaking class.

\section{Contrast between Traditional Teaching Design and Visible Teaching Design}

Generally speaking, a teaching designing mainly includes teaching objectives, important and difficult points of teaching, teaching methods, teaching procedure, teaching instruction and so on.

Traditional teaching design mainly focuses on how teachers teach. Its teaching objectives are based on the analysis of teaching material and then carry out teaching base on it. To some extents, teachers are expounders. While in visible learning design, teaching objectives are based on students' prior achievements and their goals. Teaching is to help students to achieve the goals and enable students learn how to learn. A teacher should be a tutor, a friend and an evaluator. More importantly, appropriate mind frame combine with appropriate actions, these two elements work together to achieve a positive learning effect (John Hattie, 2013).

\subsection{Differences in Teaching Objectives}

Traditional teaching design usually aims in students' acquirement of the written ability of target language. It attaches importance to language structure and grammar. Visible teaching design sets the goal under the precondition of knowing which level students have achieved and there is a way to know whether goal is achieved after class (John Hattie, 2012). Furthermore, the teaching objectives and success criteria are both clearly explained before class.

\subsection{Differences in Teaching Process}

Traditional teaching design focuses on how teachers teach with the pattern of emphasizing recitation, imitation, recitation, repetition that attach importance to the structure and function of language(Zhou Dandan, 2019). The teaching process is to analyze grammar of target language first and then translate it into native language. It advocates the mechanical comparison of the two languages and translates word by word, or sentence by sentence. The translation is both teaching objective and teaching method (Sun Xia \& Wei Qiwei, 2016). As for visible learning, without any fixed teaching pattern, it focuses on how students learn. The process of teaching will use the teaching strategies accordingly to provide instructions in the right way, requiring teachers' awareness of what students have learned and their desired results, constantly keeping an eye on the difficulty of the activities they have adopted and students' response, to ensure the progress of learning.

Moreover, traditional teaching design attaches importance to teachers' lecture; a class is carried out with more teacher instructions and less listening. Students are receivers with little chance to express their ideas. Therefore they will easily loose interests or only learn the knowledge in textbooks. Visible teaching design, on the contrary, with reduce teacher talking. Teachers only speak when it' $s$ necessary and students have plenty of chances to share their opinions. Through this method, students will become more active. It helps to foster higher-order learning, which allows teachers to know students' understanding and then carry out fellow-up teaching.

What's more, the role of peer and tutor are another two important elements in visible teaching design. VB values the impact of peers and tutor for they have more effective influence than individualistic learning in implementation when students have enough knowledge and the activities are well instructed.

\subsection{Differences in Evaluation and Feedback}

The mastery of reading and witting ability is the main consideration in traditional teaching design; speaking and listening abilities and action-oriented competence that can integrate students' overall quality are often neglected. Visible teaching design involves these elements when evaluating the class and figuring the actions. Furthermore, conditions that pose positive effects on students are also considered as part of the bases that modify teachers' class design and their teaching. 
VB also values feedback which does not merely keeps students attentive, and it gives timely response to students and checks students' understanding in teaching process and after class. It also works as the tool that helps students to reduce the informational gap.

\section{WAYs to FACILITATE TEACHING DeSign}

\subsection{Set Proper Teaching Objectives and Difficult Points}

The knowledge objects in middle school English listening and speaking class are always given prominence rather than ability aims. While students want to archive a better competence though listening and speaking lesson with their ability to communicate and to understand what they have heard in conversation, combined with students' desired level and their starting level, the teaching goals which should not only be challenging but also explicit. Furthermore, students can strike to achieve the goals by hardworking and teachers can use appropriate modifications to ascertain the accomplishment of the goals.

Difficult point of teaching is although students can sophisticatedly practice the exercises in book after learning, but when comes to practice with their own experiences, it begins to be difficult for them and the fluency of their expressions would largely reduced or limited. To improve it is to provide students with more chances of practicing, an expressive atmosphere and practical advice. Moreover, teachers should pay attention to students' daily accumulation of vocabularies and phrases in their teaching. When these words and sentences appear, teachers need to emphasize them and use them in the following teaching.

These suggestions aim to help students to cultivate the habit of taking the first step and foster students' ability to study on their own and finally, become their own teacher.

\subsection{Instruct with Meaningful Activities}

In the premise of ensuring the accomplishment of teaching objectives, teaching should be a feasible and flexible form. Teachers need to pay their attention to the proper degree of the activities they carry in class and students' reaction to ensure the upward process of learning. Different from reading and writing class, listening and speaking class requiring a certain communicative environment where students have chances of listening and then presenting their ideas, through which they will be able to communicate in contextual environment. The teaching materials can sometimes be difficult to stimulate students' thinking and they would easily get bored with class. Therefore, tasks with little meaning can be replaced by tasks that are stimulating like games, discussions that students are voluble and can express their personal views. Teachers need to clearly explain the task and be careful in keeping students attentive when implementing these activities.

Middle school English listening and speaking class usually carry out along the instruction of teacher; teacher' instruction plays an exclusive role of leading the class and doing practice. VB (visible learning) teaching design asks teachers to talk less and listen more. Teachers speak only when they need to present topics, explain language points, and ensure the class goes smoothly (John Hattie, 2012). Given more chances to speak, paved the surface knowledge of new lesson, students are less likely to be bothered and at the same time they would found they that can talk more with the help of given knowledge. And in the whole teaching process teachers should encourage and response positively and students will feel their opinions were respected and valued, in which students are more likely to build confidence and interest of English learning.

The role of peer is also considerable, compared with individualistic learning; it has more positively impact on students (John Hattie, 2012). Teachers can apply it to teaching by asking students to do pair work or report the result of the group discussion. By peer works students can interchange their views, catch up with the lesson. And they would form a sense of belonging and build friendships with classmates.

\subsection{Evaluate with Standardization}

Test results should not be the sole evaluation criterion of students' progress; other elements should also be included. Evaluation criterion is for students and teachers to check whether they have achieved the goal (John Hattie, 2012). It should be practical, challenging and realizable. Teachers can set some specific evaluation standards like how long students can express themselves on a topic before and 
after learning or how much they can understand in the conservation, with these clear standards it would be easier for teachers and students to check the progress that they made.

To give effective feedback, teachers need to gain a clear cognition of where students are and where it was planned to be in class. Teachers can appeal feedback questions like "Where am I going? How am I going there? Where to next? (John Hattie, 2012)" to help student reexamine where they are, and what they are learning. And teachers can also tell students whether the answer is correct or offering the similar answer for discrimination, to build their surface understanding of knowledge. Teachers can also ask students some reflective questions like finding the mistake to encourage their critical thinking and further learning.

\subsection{Value Self-Development}

Teacher should be a tutor who teaches, preaches, imparts and disabuses; a friend who has a fair and good relation with his students and most importantly an evaluator who assesses his effects on students' learning and makes full use of the conditions that attribute in students' learning to achieve a better class design and foster a positive learning environment. Meanwhile, students' behavior in class is also closely related with the teacher, they appear to be more active and attentive when the lesson was given by teachers they like.

Teachers, as the participant and giver of class, need to pay attention to their self-development, not only in teaching, but also in their consciousness and attitude. By paying attention to how students learn and observing successful teaching examples, teachers can learn how to teach. More importantly, they can evolve a custom of learning to teach and improve their teaching.

\section{CONCLUSION}

The English listening and speaking class in middle school requires a growing attention and practical ways to facilitate it, through which the class will become more and more student based and ability oriented. Yet as time passed by, the importance of student's listening and speaking competence will be treated in perspective. Simultaneously the English class will focus on learner's comprehensive capacity rather than one particular aspect. Tough the significance of English listening and speaking class today is still underestimated with problems and deficiencies existed.

Along with the status of middle school English listening and speaking class, teaching theories and the data gathered though questionnaire, the study discussed and tried to propose some practical solutions based on analyses of these theories and data.

However, this paper is merely a plain attempt in middle school English listening and speaking class teaching design, the data gathered may have errs and with a number of 99, which can be a little less. And the suggestions may not have covered an all-round view. Besides, there is no best way of teaching but the most suitable way for students.

Keep up with the progressing of the society, English listening and speaking class teaching design in middle school will continually to be improved alone with this process.

\section{REFERENCES}

[1] Rebecca A. \& Jonathan N. TBLT in Asia: Constrains and Opportunities [J]. Asian Journal of English Language Teaching 19 (1): 1-17, 2009.

[2] John, H. Visible Teaching for Teachers Maximizing Impact on Learning [M]. London and New York: Routledge, 2012.

[3] John H. \& Gregory C.R. Yates. Visible Teaching and the Science of how we Learn [M]. London and New York: Routledge. 2013.

[4] John H. Teacher-Ready Research Review The Applicability of Visible Learning to High School[J]. Scholarship of Teaching and Learning in Psychology (1): 79-91, 2015.

[5] 方文礼. 外语任务型教学法纵横谈[J]. 《外语与外语教学》2003 (9.1) : 17-20.

[6] 贾志高. 有共任务型教学法的几个核心问题的探讨[J]. 《课程·教材.教法》2005（25.1）:51-55.

[7] 孙霞\&韦启卫. 传统教学法与交际教学法在初中英语教学中的对比研究[N]. 黔南民族师范 学院学报》2016(5):58-61 
Visible Teaching Design of Middle School English Listening and Speaking Class from the Perspective of Task-Based Teaching

[8] 徐盛. 基于任务型教学的初中英语听说课活动设计与实施效果的实证研究[D]. 南京师范大学. 2017

[9] 周丹丹. 中国传统教学法及其语言习得机制的当代构建[J]. 《江海学刊》2019(2): 243-248

\section{AUTHORS' BIOGRAPHY}

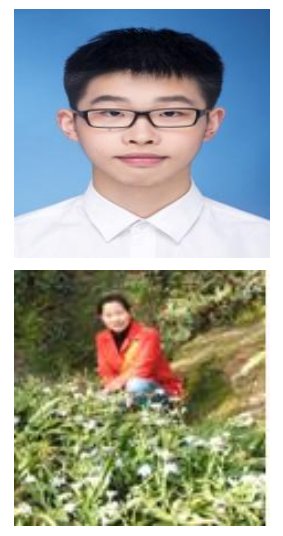

Zifan Tang was born in Jiashan, China in 1998. He is a third-year English Major in Zhejiang Ocean University

Qiang Liu was born in Zhoushan, China in 1978. She received her M.A. degree in Foreign Linguistics and Applied Linguistics in Zhejiang Normal University, China. She is an associate professor in the School of Foreign Languages, Zhejiang Ocean University, China. She current researches focus on English Teaching.

Citation: Zifan Tang, Qiang Liu. "Visible Teaching Design of Middle School English Listening and Speaking Class from the Perspective of Task-Based Teaching". International Journal of Humanities Social Sciences and Education (IJHSSE), vol. 6, no 8, 2019, pp. 78-85. doi: http://dx.doi.org/10.20431/2349-0381.0608008.

Copyright: (C) 2019 Authors. This is an open-access article distributed under the terms of the Creative Commons Attribution License, which permits unrestricted use, distribution, and reproduction in any medium, provided the original author and source are credited. 